IRA-International Journal of Education \& Multidisciplinary Studies

ISSN 2455-2526; Vol.03, Issue 03 (2016)

Institute of Research Advances

http://research-advances.org/index.php/IJEMS

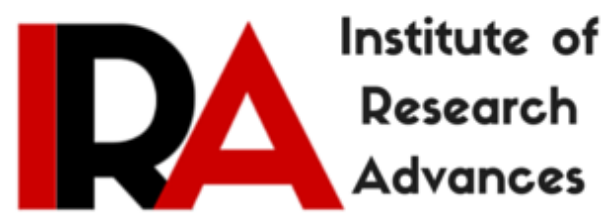

\title{
E-Learning in TVET: An Opportunity for Developing Countries
}

\author{
${ }^{1}$ Makworo Edwin Obwoge \& ${ }^{2}$ Okemwa Stela Kwamboka \\ ${ }^{1}$ KISII University \\ P.O Box 408 - 40200, KISII, Kenya. \\ 2 The Kabete National Polytechnic \\ P.O Box 29010 - 00625, Nairobi, Kenya.
}

DOI: http://dx.doi.org/10.21013/jems.v3.n3.p8

\section{How to cite this paper:}

Edwin Obwoge, M., \& Stela Kwamboka, O. (2016). E-Learning in TVET: An

Opportunity for Developing Countries. IRA International Journal of Education and

Multidisciplinary Studies (ISSN 2455-2526), 3(3).

doi:http://dx.doi.org/10.21013/jems.v3.n3.p8

(C) Institute of Research Advances

\section{(c) EY-NC}

This works is licensed under a Creative Commons Attribution-Non Commercial 4.0 International License subject to proper citation to the publication source of the work.

Disclaimer: The scholarly papers as reviewed and published by the Institute of Research Advances (IRA) are the views and opinions of their respective authors and are not the views or opinions of the IRA. The IRA disclaims of any harm or loss caused due to the published content to any party. 


\begin{abstract}
Education systems in the world today are undergoing major shifts in their delivery systems to be able to accommodate shifting demands in the lifestyles of people. ICT has greatly influenced the way institutions operate in reaching and providing services to their clients. Many educational institutions have adapted their situations to meet the work demands and changing trends in education by adopting e-learning as a mechanism to reach the students who may have no time to sit in class due to their nature of work. TVET systems in Africa are slowly and steadily also starting to move towards implementing elearning in their teaching learning process. This paper gives insight into the potential and situation of e-learning in TVET institutions in developing countries in Africa and points out major recommendations on how to improve in order to inform policy makers and other stakeholders in the TVET sector.
\end{abstract}

Key Words: ICT, e-learning, TVET, Developing countries

\title{
Introduction
}

The global development agenda in the $21^{\text {st }}$ century is greatly shaped by the existing education systems in the world today. The developed economies enjoy a lot of freedom and flexibility in their education systems because of advanced technology. The physical development of a nation is greatly influenced by the skills harboured by its citizenry drawn from the existing education system. Many countries have enhanced their development by fostering well organized and linked TVET systems. TVET is an education that prepares people for specific trades, crafts and careers at various levels from a trade, a craft, technician, or a professional position in engineering, accountancy, nursing, medicine, and other healing arts, architecture, pharmacy, law etc. Most vocations are usually based on manual or practical activities, traditionally non-academic, related to a specific trade, occupation, or vocation.

Most TVET institutions in developing countries apply traditional methods in teaching and learning delivery where a learner must be physically present in class and the teacher is mostly the source of the content while the learner is only a recipient. The current dynamic education and work environment necessitates a shift from the norm. The role of ICT in the growth and development of the developing economies cannot be underestimated. The education sector stands out to be one of the greatest beneficiaries of the information communication technologies. Many developing countries greatly rely on skilled labour to enhance their development agenda and as pointed out by many professionals, TVET is the master key to development.

E-learning has been defined differently in different literature. In general, e-learning is the expression broadly used to describe "instructional content or learning experience delivered or enabled by electronic technologies" (Ong, Lai and Wang, 2004). According to Jones (2003), some definitions of e-learning are more restrictive than this one, for example limiting e-learning to content delivery via the Internet. However, the most educators consent that e-learning is a set of synchronous and asynchronous instruction delivered to learners over technology (Colvin and Mayer, 2008).

E-Learning is a very important resource to be drawn on to maximize on learning opportunities in developing economies. The traditional modes of delivery are restrictive in accessibility of learning resources by the students. According to Franklin and Peat, 
2001; Brown, 2004 and Liaw, 2008, the traditional system of education and e-learning are considered to be quite different. E-learning provides a flexible system of information dissemination which is not confined to only regular day time activities but can also take place in a variety of locations including homes, schools, libraries internet cafes and open fields. With e-learning, the TVET instructors will be able to reach learners in different set-ups using the available diverse ICT resources. This will reduce the limitation of time, space and place that have become a great hindrance and challenge to education delivery especially for the working class. The TVET learners will also greatly benefit by having a variety of choices in course completion modes and a lot of flexibility in learning delivery leading to lifelong learning.

\section{Challenge of e-learning in TVET in developing countries}

In developing countries, there are major barriers leading to minimal and ineffective use of technology within the Learning institutions. This include lecturers' attitudes and resistance to change which is majorly due to lack of skills in ICT use since traditionally this was not covered within the TVET teacher training curriculum or if covered it was shallow and unfocused since most of the new technologies were not there then. Another major barrier is lack of adequate funding to develop infrastructure, train instructors and support staff in ICT implementation and application. This has hence led to poor administrative support in the TVET institutions hence leading to the current state of very low motivation and adoption rate of ICT in teaching and learning in these institutions in developing countries in Africa. Challenges of the use of ICT in TVET are not only experienced in Africa, according to studies carried in Central Asia, the use of the Internet in teaching and learning is largely absent from TVET classes even where institutions are internet connected. Most ICT use in TVET schools is directly related to the teaching of basic ICT skills and, specifically, to the use of basic software applications. There is little use of ICT in the teaching of technical subjects and skills under TVET programs, where it has obvious applications. Similarly, the development of ICT-based distance education in technical and vocational subjects has been limited to date.

The integration of ICT technologies in the current education systems has brought about a significant paradigm shift in the teaching and learning process which requires instructors to have adequate training in technology and also availability of adequate technical support (Rogers \& Donna, 2003). The TVET institutions in developing countries are faced with an urgent need to develop their staff in order to help them be up to date with current technologies available for instruction delivery and also to have the requisite knowledge required to plan and deliver out of school learning content. The institutions should also come up with programs to train technicians in ICT technologies to ensure sustainability of the projects.

According to Oketch H. A., Njihia J. M. \& Wausi A. N. (2014), there is need for institutions to provide leadership in educational technology to produce holistic students ready to work in this digital era. TVET institutions in developing countries must pick up this challenge and foster competency based education delivery for the aspired development to be realized. 


\section{Role of e-learning in TVET in developing countries}

According to Hall (2001), institutions that have implemented use of technology in learning are witnessing a number of benefits such as cost savings and increased flexibility in productivity. This is because there is reduced cost of infrastructure needed to accommodate learners within the school environment and with the many ICT technologies, now learners can be reached without necessarily being bound to the school compound. E-learning also makes learners more independent Institutions that have implemented ICT have also maintained a competitive edge against their counterparts (Goldstein and Ford, 2001.) According to Karmakar (2000), e-learning creates opportunities for organizations in the following ways: save time, cost, and effort; satisfy educational needs from remote areas; provide self-learning opportunities; have a positive impact on the learning process and provide a mechanism for collaborative learning.

According to Lohento (2013), in a survey carried out in some African countries, respondents were asked to express what they had experienced to be the effect of digital technologies on learning outcomes within their respective organizational contexts. The majority of responses were positive, with $71 \%$ saying the effects have been positive and only $1 \%$ saying the effects have been negative. A total of 268 respondents chose to explain the ways in which technology is leading to an improvement in learning outcomes and this was categorized in themes as shown in figure 1

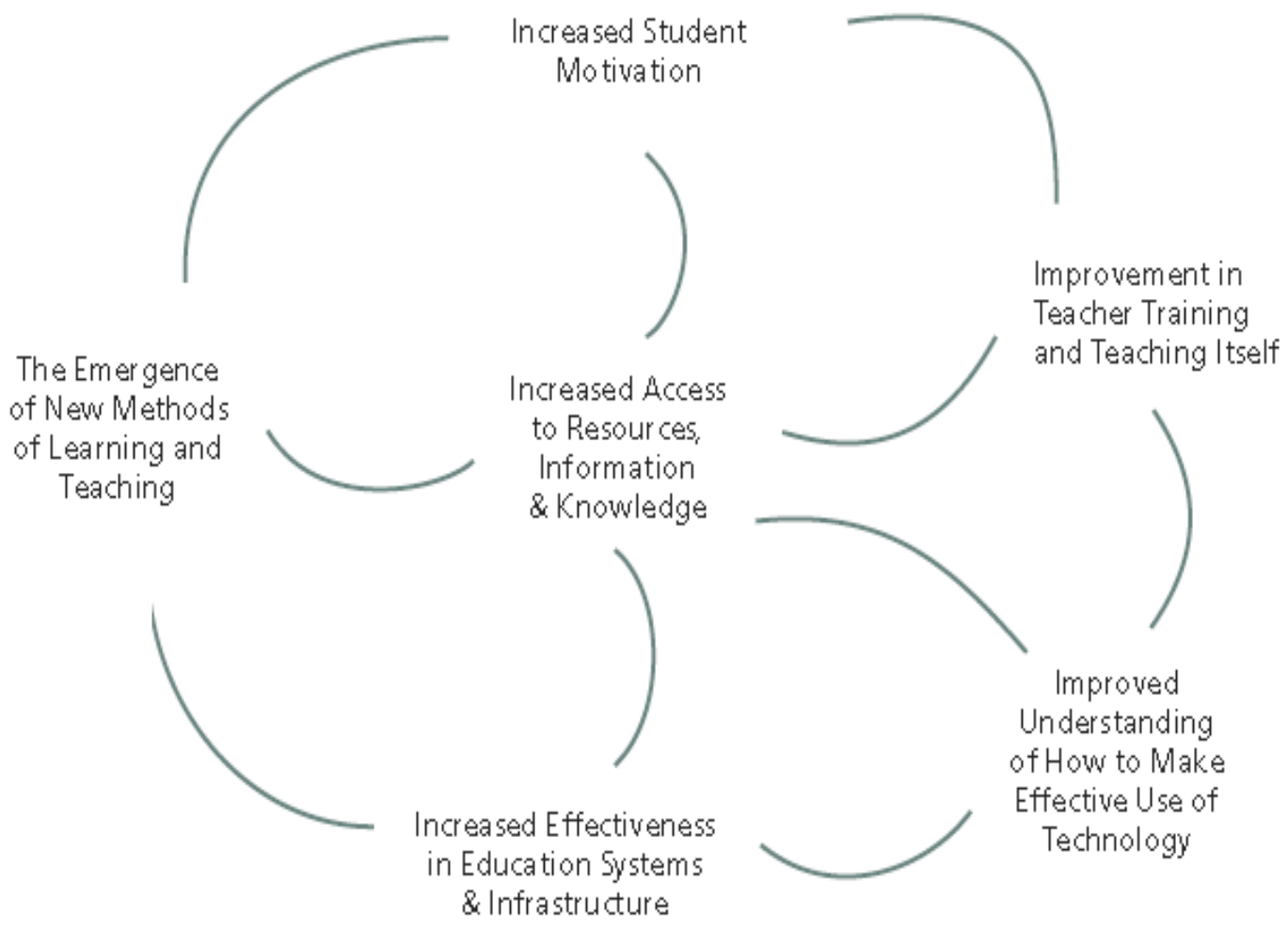

Figure 1: How Digital Technology Integration Enables Positive Learning Outcomes 
It is very evident that digital technologies have a great potential of enriching the education systems in developing countries and TVET can tap from this to enhance its delivery systems.

\section{Conclusion}

Although there is great potential for e-learning in TVET, there seems to be great laxity in implementation of e-learning in TVET institutions in developing countries mainly aggravated by limited funding opportunities. Even so, e-learning is the right direction to move towards for TVET institutions in developing countries. All TVET stakeholders should come together and work towards a common agenda of embedding e-learning within the TVET system in order to reap the many benefits of ICT. There should also be gradual investment in e-learning in developing countries in order to increase prospects of future growth and development in these economies.

\section{Recommendations for TVET institutions in developing countries}

The following recommendations can inform stakeholders within the TVET sector in developing countries in their planning and implementation of E-learning delivery systems both at TVET institution management level and also in the teaching learning process.

1. The TVET institutions in developing countries should carry out e-readiness surveys in order to determine their status and hence fast track acquisition and installation of any missing ICT resources for improved delivery of in-school and out of school learning content.

2. The relevant education ministries in the developing countries should develop a programme with relevant stakeholders to offer training to the current instructors in TVET institutions on planning and delivering learning content using e-learning technologies. This will help them be equipped with skills and knowledge in content selection for inclusion, assessment models and student follow-ups.

3. The TVET teacher training Institutions in developing countries should include relevant courses on use of ICT in instruction delivery to ensure that any new instructors coming out of their systems are ready to fit into the new workplace set-up. This should be done in collaboration with the responsible education ministries and relevant stakeholders.

4. The governments of the developing countries should allocate adequate funds to TVET sector to facilitate acquisition and installation if necessary ICT infrastructure.

\section{REFERENCES}

Colvin, R \& Mayer, R. 2008. E-learning and the science of instruction. California: John Wiley.

Jones, A. J. (2003). ICT and Future Teachers: Are we preparing for e-Learning? IFIP Working Groups 3.1 and 3.3 Conference: ICT and the Teacher of the Future, Melbourne, Australia.

Karmakar, C. K. (2000). Recommendations for Bangladesh towards e-learning readiness. Department of computer science, Shah Jalal University of science and technology. 
Oketch H. A., Njihia J. M. \& Wausi A. N. (2014). E-Learning Readiness Assessment Model in Kenyas' Higher Education Institutions: A Case Study of University of Nairobi. International Journal of Scientific Knowledge Computing and Information Technology. Vol. 5, No.6 pg 29-41.

Ong, C.S., Lai, J.Y. \& Wang, Y. S. (2004). Factors Affecting Engineers "e Acceptance of Asynchronous E-learning Systems in High-Tech Companies. Information and Management, 41 (6), 795-804, p.01.

Rogers, E. M. (2003). Diffusion of innovations. New York.

Lohento, K (2013). Seeds 2.0 to Modernise and Boost the Agricultural Sector. The elearning Africa report. Namibia. 